\title{
Tripleurospermum maritimum from a coastal shingle beach: nitrophilic status, tolerance to salinity and heavy metals
}

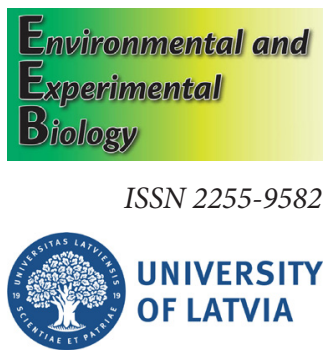

\author{
Gederts levinsh ${ }^{1 *}$, Una Andersone-Ozola ${ }^{1}$, Andis Karlsons ${ }^{2}$, \\ Anita Osvalde ${ }^{2}$
}

${ }^{1}$ Department of Plant Physiology, Faculty of Biology, University of Latvia, Jelgavas 1, Rìga LV-1004, Latvia

${ }^{2}$ Institute of Biology, University of Latvia, O. Vācieša 4, Rīga LV-1004, Latvia

${ }^{\star}$ Corresponding author, E-mail: gederts.ievins@lu.lv

\begin{abstract}
Tripleurospermum maritimum is a species characteristic for several protected sea coast habitats. The aim of the present study was to investigate possible nitrofilous status, tolerance to salinity and heavy metals, as well as the metal accumulation potential of T. maritimum plants from a sea-affected coastal habitat in controlled conditions. Plants were cultivated in an automated greenhouse in containers with a substrate made from garden soil and quartz sand. Three separate experiments were performed: (i) plants received combined treatment of three different doses of mineral fertilizer plus additional $\mathrm{NO}_{3}-\mathrm{N}$ or $\mathrm{NH}_{4}-\mathrm{N}$; (ii) plants were treated with increasing concentration of $\mathrm{NaCl}$; and (iii) plants were treated with increasing concentration of $\mathrm{Cd}$ or $\mathrm{Pb}$. After seven weeks of cultivation, plant morphological characteristics, soluble ion concentration in tissue extracts and tissue $\mathrm{Cd}$ and $\mathrm{Pb}$ concentrations were measured. Increase in mineral nutrient availability stimulated shoot growth of T. maritimum plants. Addition of $\mathrm{N}$ fertilizer resulted in further increase of shoot biomass by 20 to $30 \%$. Plants exhibited good tolerance to increased $\mathrm{Na}^{+}$concentration, with only about $30 \%$ reduction in shoot biomass at $5 \mathrm{~g} \mathrm{~L}^{-1}$. High electrolyte accumulation potential was evident in shoots, with preferred accumulation of $\mathrm{K}^{+}$over $\mathrm{Na}^{+}$. Tolerance to heavy metals was very high, as growth of plants was not affected even in $100 \mathrm{mg} \mathrm{L}^{-1} \mathrm{Cd}$ treatment. Root biomass of plants treated with 500 $\mathrm{mg} \mathrm{L}^{-1} \mathrm{~Pb}$ was reduced only by $35 \%$, while shoot growth was unaffected. Both $\mathrm{Cd}$ and $\mathrm{Pb}$ were preferentially accumulated in roots of $T$. maritimum, with concentration in aboveground parts being less than $10 \%$ from that in roots. In conclusion, the coastal accession of $T$. maritimum from a shingle beach is moderately nitrophylic with high salinity tolerance and very high tolerance to heavy metals, with characteristic exclusion of the metals from aboveground parts.
\end{abstract}

Key words: coastal species, electrolyte accumulation, mineral fertilizer, heavy metals, nitrogen, salinity, shingle beach, Tripleurospermum maritimum.

Abbreviations: DM, dry mass.

\section{Introduction}

Coastal species from seawater-affected habitats are promising models in studies of plant adaptation mechanisms to soil chemical heterogeneity. These habitats are highly dynamic in respect to nutrient availability, substrate salinity as well as presence of heavy metals, creating a need for well-balanced mechanisms to provide chemical homeostasis of cells and tissues (Ievinsh 2006).

Several species of the genus Tripleurospermum (Asteraceae) can be found in coastal habitats, including Tripleurospermum martimum (L.) W.D.J.Koch (syn. Matricaria maritima L.) and Tripleurospermum inodorum (L.) Sch.Bip. [syn. Matricaria inodora L., Matricaria perforata Mérat, and Tripleurospermum perforatum (Mérat) M.Lainz]. Sometimes the two species are regarded as subspecies of T. maritimum (or T. inodorum) due to a large phenotypic plasticity (Kay 1994). Both species are generally considered as common weeds. T. maritimum is a biennial or short-lived perennial plant found on salt-affected driftlines and sea-cliff habitats on the coasts of western and northern Europe (Kay 1972). It is a characteristic species of the European protected habitats EUH 1230 "Vegetated sea cliffs of the Atlantic and Baltic coasts" and EUH 1330 "Atlantic salt meadows (Glauco-Puccinellietalia maritimae)" (EC 2013).

According to recently established ecological indicator values, T. maritimum in Sweden is characterized as favoured by moderate salinity, but not restricted to saline habitats (indicator value 3 out of 5) and can be found on extremely $\mathrm{N}$-enriched soils (indicator value 9 out of 9) (Tyler et al. 2021). Consequently, T. maritimum can be expected to represent coastal-specific nitrofilous species with moderate salinity tolerance. In sea-affected habitats, $T$. 
maritimum can be characterized as a moderately $\mathrm{Na}^{+}$- and $\mathrm{K}^{+}$-accumulating species behaving as a tight regulator of electrical conductivity in tissue water (Ievinsh et al. 2021). Only one study so far aimed at experimentally revealing salinity tolerance of T. maritimum (syn. M. maritima), using seed material from littoral dunes on the Atlantic coast in France (Ben Hamed et al. 2014). As a result, it was characterized as an intermediately salinity tolerant, $\mathrm{Na}^{+}$-including species. However, based on observations performed in the Eastern Greenland, it was suggested that T. maritimum represents "a long-lived halophyte well able to withstand competition from other strand species" (Corner 2012). In addition, salinity tolerance of several taxonomically related species (Matricaria chamomila L. and Matricaria recutita L.) has been assessed for practical reasons (Baghalian et al. 2008; Razmjoo et al. 2008; Heidari, Sarani 2012).

There is no information on heavy metal tolerance of $T$. maritimum available in the literature, but there are several reports concerning several taxonomically closely related species. For example, when cultivated in hydroponics, $M$. chamomilla has been shown to be tolerant to cadmium (Kováčik et al. 2006; Farzadfar et al. 2013), partially tolerant to $\mathrm{Cu}$ (Kováčik et al. 2008) and highly tolerant to $\mathrm{Ni}$ (Kováčik et al. 2009). Also, M. recutita has shown high tolerance to Cd (Pavlovič et al. 2006). Native presence of $M$. chamomilla in soils heavily contaminated with heavy metals $\mathrm{Cd}$ and $\mathrm{Pb}$ also indicates high metal tolerance status of the species (Voyslavov et al. 2013). Based on the mentioned results, heavy metal tolerance of T. maritimum can be proposed.

The aim of the present study was to investigate possible nitrofilous status, tolerance to salinity and heavy metals, as well as electrolyte and the heavy metal accumulation potential of T. maritimum plants from a sea-affected coastal habitat in controlled conditions of a vegetation container study.

\section{Materials and methods}

Seeds from a coastal accession of T. maritimum collected on shingle beach of the Baltic Sea in Ohesaare, Saaremaa Island, Estonia, growing within $2 \mathrm{~m}$ zone from a waterline, were used to establish the species in cultivation in conditions of an automated greenhouse. Seeds were dried in laboratory conditions for one month and then were stored at $4{ }^{\circ} \mathrm{C}$. Procedures used for plant establishment as well as cultivation conditions in greenhouse are described in detail previously (Andersone-Ozola et al. 2021). Briefly, seeds were surface sterilized with $5 \% \mathrm{NaOCl}$, imbibed in water and germinated in autoclaved substrate (Garden Soil, Biolan, Finland) in plastic plant tissue culture containers in a growth cabinet. Established seedlings with the two true leaves were individually transplanted first to $250 \mathrm{~mL}$ plastic containers and after two weeks to $1.3 \mathrm{~L}$ plastic containers filled with a mixture of heat-treated substrate containing Garden Soil and quartz sand (1:1, v/v). Plants were cultivated in an experimental automated greenhouse with supplemented light $\left(380 \mu \mathrm{mol} \mathrm{m} \mathrm{m}^{-2} \mathrm{~s}^{-1}\right.$ at the plant level) with $16 \mathrm{~h}$ photoperiod, day/night temperature 24/16 ${ }^{\circ} \mathrm{C}$, and relative air humidity 60 to $70 \%$. Substrate water content was kept at 50 to $60 \%$ using deionized water.

Three separate experiments were performed with 3-week-old well-established plants: (i) effect of combined treatment of three different doses of mineral fertilizer plus additional treatment with nitrogen fertilizer applied as $\mathrm{NO}_{3}-\mathrm{N}$ or $\mathrm{NH}_{4}-\mathrm{N}$; (ii) effect of increasing substrate concentration of $\mathrm{NaCl}$; and (iii) effect of increasing concentration of $\mathrm{Cd}$ or $\mathrm{Pb}$.

For the fertilizer and nitrogen treatment experiment, plants were randomly distributed in nine groups, five individual plants per group. Three different doses of mineral fertilizer were used as a basic treatment, consisting of 5, 10 or $15 \mathrm{~mL}$ or $1 \%$ mineral fertilizer Kristalon Red (Yara Tera, Norway) per individual plant per week. For each of these groups, plants either did not receive additional fertilizer or were treated biweekly with $\mathrm{Ca}\left(\mathrm{NO}_{3}\right)_{2}$ or $\left(\mathrm{NH}_{4}\right)_{2} \mathrm{SO}_{4}$, equalized in respect to $\mathrm{N}$ concentration $(0.15 \mathrm{~g} \mathrm{~N}$ per plant). After the start of the treatment, plants were cultivated for seven weeks.

For the salinity experiment, plants were randomly distributed in five groups, five individual plants per group: control, $\mathrm{Na} 0.5, \mathrm{Na} 1, \mathrm{Na} 2$, and $\mathrm{Na} 5$ (in $\mathrm{g}$ of $\mathrm{Na}$ per $1 \mathrm{~L}$ substrate). Plants in each group were irrigated with 200 $\mathrm{mL}$ deionized water or $200 \mathrm{~mL}$ deionized water with $2.54 \mathrm{~g}$ $\mathrm{NaCl}$ twice a week until the respective final concentration was reached. After the start of the treatment, plants were cultivated for seven weeks.

For the heavy metal experiment, plants were randomly distributed in seven groups, five individual plants per group: control, Cd 10, Cd 50, Cd 100, Pb 100, Pb 200, and $\mathrm{Pb} 500$ (in mg of metal per $1 \mathrm{~L}$ of substrate). For respective treatments, $\mathrm{CdCl}_{2}$ and $\mathrm{Pb}\left(\mathrm{CH}_{3} \mathrm{COO}\right)_{2} 3 \mathrm{H}_{2} \mathrm{O}$ were used in necessary dilutions in deionized water. After treatment, plants were cultivated for seven weeks.

At the termination of experiments, plants were individually separated in different parts (roots, stems, leaves) and both fresh and dry mass (after drying in an oven) was measured. Water content was calculated as $\mathrm{g}$ $\mathrm{H}_{2} \mathrm{O}$ per g dry mass.

Dried tissue samples $(0.2 \mathrm{~g})$ were used for estimation of electrical conductivity, $\mathrm{Na}^{+}$and $\mathrm{K}^{+}$concentration. Tissues were ground with mortar and pestle to a fine powder and 10 $\mathrm{mL}$ of deionized water was added. After filtration through nylon mesh cloth (No. 80) homogenate was used for measurement of electrical conductivity by a LAQUAtwin conductivity meter B-771 and ion concentration by LAQUAtwin compact meters B-722 $\left(\mathrm{Na}^{+}\right)$and B-731 $\left(\mathrm{K}^{+}\right)$. Concentration of $\mathrm{Na}^{+}$and $\mathrm{K}^{+}$was calculated as mass units both on dry biomass as well as on tissue water content basis 
as molar units. Electrical conductivity was expressed on dry biomass was well as tissue water basis. All measurements were performed in five biological replicates, representing tissue samples from individual plants.

Concentration of $\mathrm{Cd}$ and $\mathrm{Pb}$ was measured in dried tissues of all plant parts. Each sample consisted of about 2 g plant material. Samples were fixed 2 to $3 \mathrm{~min}$ at $105^{\circ} \mathrm{C}$, then dried at $60^{\circ} \mathrm{C}$ to constant weight and ground. The test solution was prepared by dry ashing plant tissues with $\mathrm{HNO}_{3}$ vapour and re-dissolving in 3\% $\mathrm{HCl}$ solution (Rinkis et al. 1987). The test solution was used for the determination of analyzed heavy metals. Microwave plasma atomic emission spectrometry (4200 MP-AES, Agilent) was used for the measurement of $\mathrm{Pb}$ and $\mathrm{Cd}$ according to manufacturer's instructions.

Results were analyzed and graphs were made with KaleidaGraph (v. 4.1, Synergy Software, USA). The Tukey HSD was used as a post-hoc test.

\section{Results}

\section{Effect of mineral nutrition and added nitrogen on growth}

In contrast to procumbent character of habitus and limited shoot growth of T. maritimum plants in native conditions, plants cultivated at optimum mineral nutrient availability in conditions of an automated greenhouse had pronounced upright habitus with intense branching and numerous inflorescences (Fig. 1).

Increase in mineral nutrient availability in substrate resulted in intensified shoot growth of plants, with an increase of up to $60 \%$ dry mass at triple fertilizer dose (Fig. 2A). Addition of $\mathrm{N}$-fertilizer either as calcium nitrate or ammonium sulphate resulted in further increase of shoot biomass by 20 to $30 \%$. However, root growth was not significantly affected by mineral nutrient availability or $\mathrm{N}$ addition in the form of ammonium sulphate (Fig. 2B). $\mathrm{NH}_{4}-\mathrm{N}$ treatment resulted in significant root biomass increase only for plants receiving an average fertilizer dose.

\section{Effect of salinity on plant growth and ion accumulation}

Plants exhibited good tolerance to increasing substrate $\mathrm{Na}^{+}$ concentration, growing normally even at $5 \mathrm{~g} \mathrm{~L}^{-1}$, with only about $30 \%$ reduction in shoot biomass (Fig. 3A). Dry mass of roots was relatively variable between individual plants, and significant decrease in root biomass was evident at $1 \mathrm{~g}$ $\mathrm{L}^{-1} \mathrm{Na}^{+}$, with no changes at further increase of salinity (Fig. 3B). Shoot height was little affected by increasing salinity, with significant reduction by about $40 \%$ only at $5 \mathrm{~g} \mathrm{~L}^{-1} \mathrm{Na}+$ (Fig. 3C).

Increasing substrate $\mathrm{Na}^{+}$concentration tended to stimulate root water content, with significant increase at 2 and $5 \mathrm{~g} \mathrm{~L}^{-1} \mathrm{Na}^{+}$(Fig. 3D). However, water content in aboveground plant parts - leaves and stems - significantly increased only at 0.5 and $2 \mathrm{~g} \mathrm{~L}^{-1} \mathrm{Na}^{+}$, but it significantly decreased in flowers at $5 \mathrm{~g} \mathrm{~L}^{-1} \mathrm{Na}^{+}$, evidently indicating faster senescence of generative parts.

Plant leaves and roots accumulated equal concentration of $\mathrm{Na}^{+}$on a dry mass (DM) basis, reaching more than 25 $\mathrm{g} \mathrm{kg}^{-1} \mathrm{DM}$ at $1 \mathrm{~g} \mathrm{~L}^{-1}$ substrate $\mathrm{Na}$ (Fig. $4 \mathrm{~A}$ ). The response was saturated at 1 and $2 \mathrm{~g} \mathrm{~L}^{-1} \mathrm{Na}^{+}$, for roots and leaves,
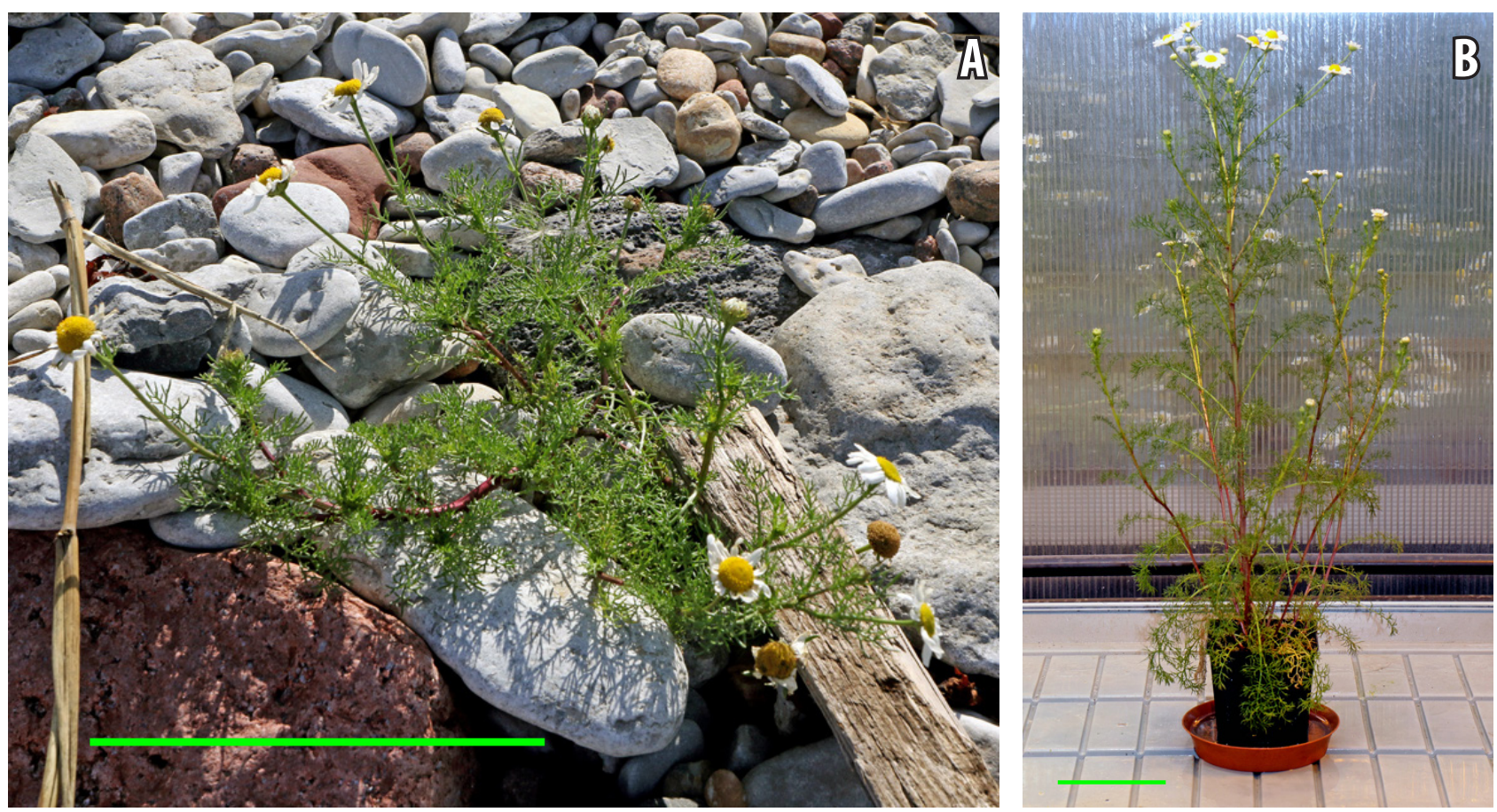

Fig. 1. Typical morphology of Tripleurospermum maritimum plants at reproductive stage growing in natural habitat of shingle beach (A) and in controlled conditions (B). Bar indicates $10 \mathrm{~cm}$. 

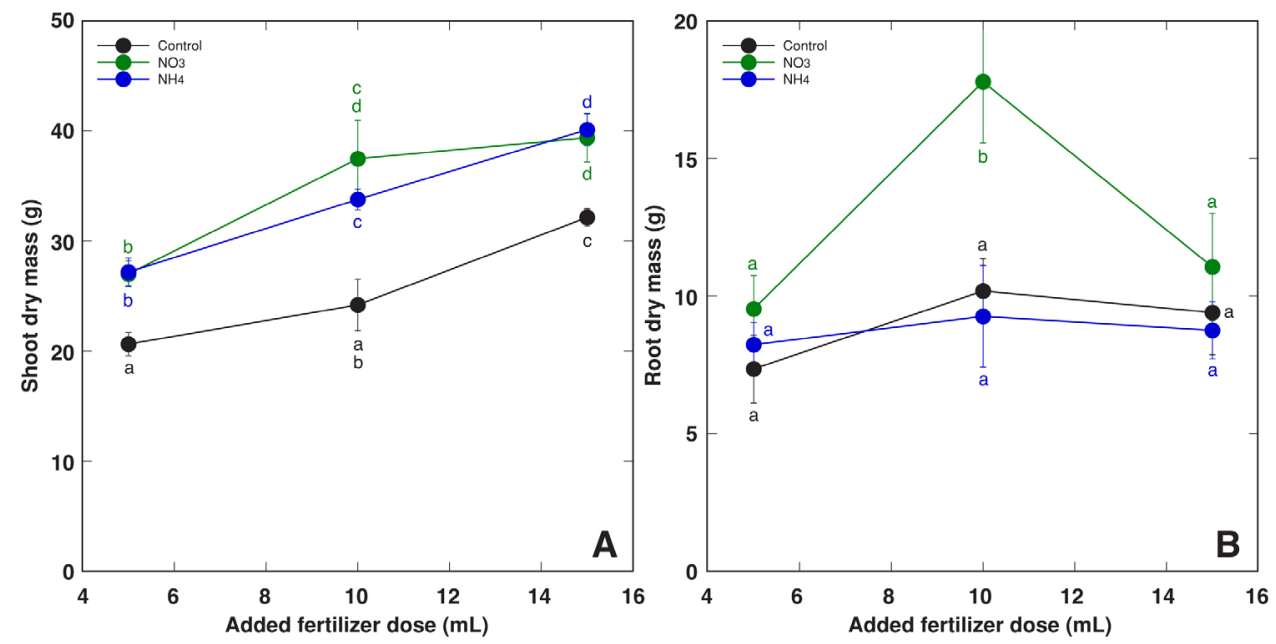

Fig. 2. Effect of increased dose of fertilizer and addition of $\mathrm{NO}_{3}-\mathrm{N}$ and $\mathrm{NH}_{4}-\mathrm{N}$ on dry mass of shoot (A) and root (B) of Tripleurospermum maritimum plants after 7 weeks of cultivation. Data are means \pm SE from 5 individual plants. Different letters indicate statistically significant differences $(p<0.05)$.
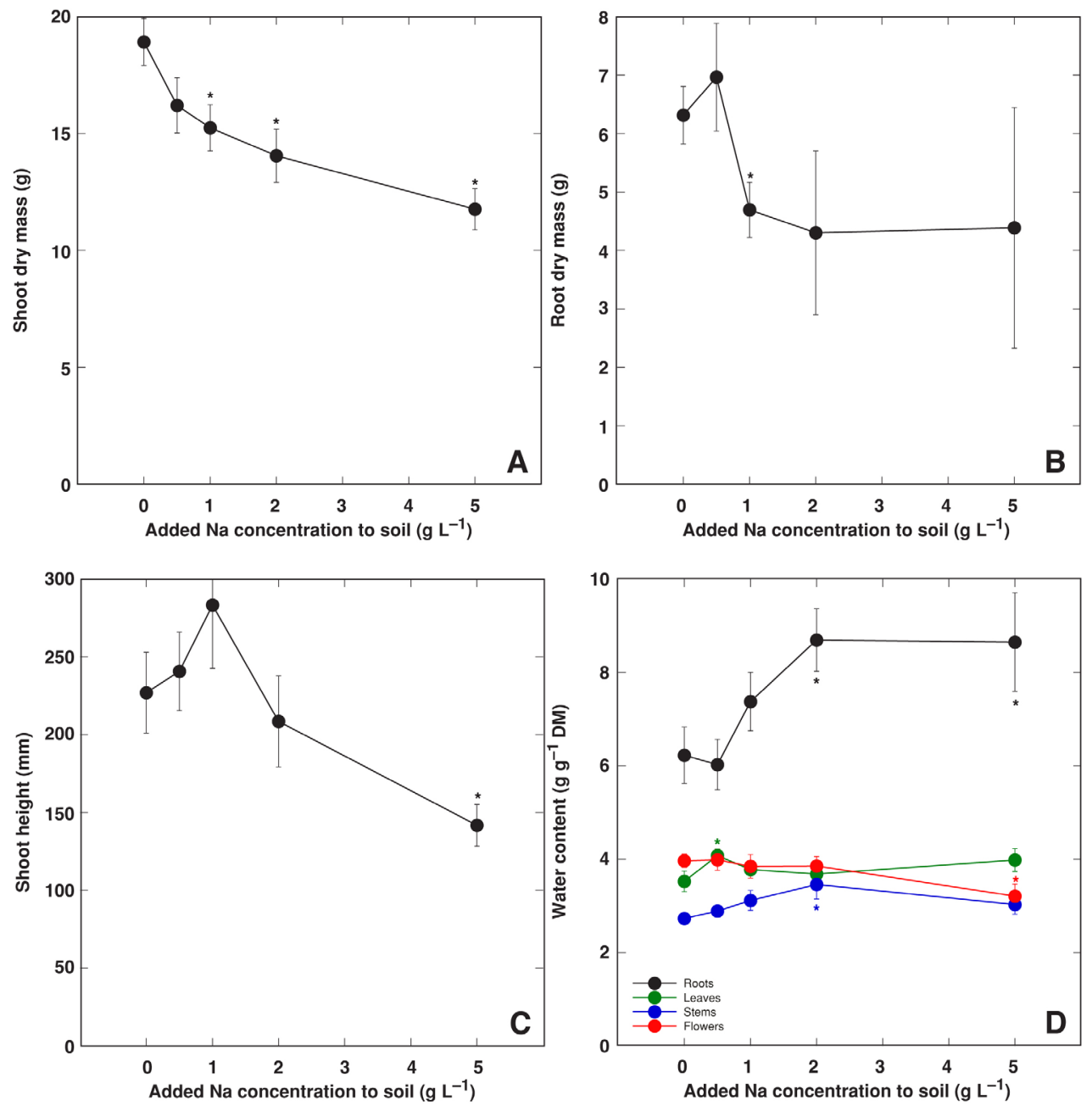

Fig. 3. Effect of increasing $\mathrm{Na}^{+}$concentration in substrate on shoot dry mass (A), root dry mass (B), shoot height (C) and water content in different parts (D) of Tripleurospermum maritimum plants after 7 weeks of cultivation. Data are means \pm SE from 5 individual plants. Asterisks indicate statistically significant differences $(p<0.05)$ from control. 

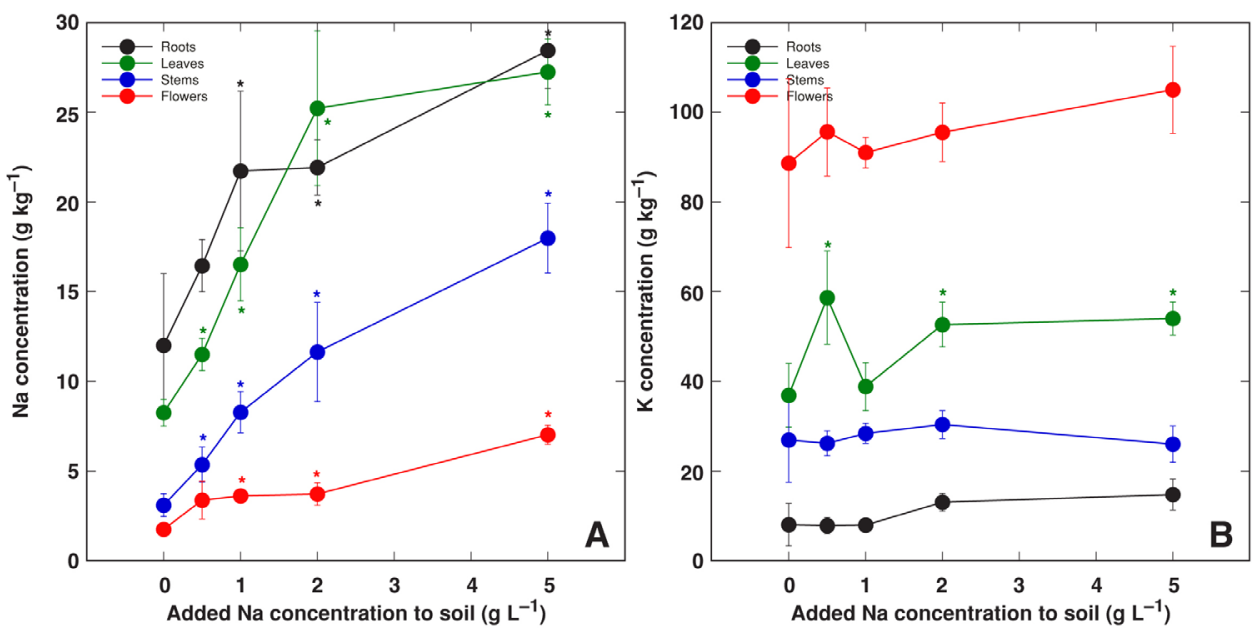

Fig. 4. Effect of increasing $\mathrm{Na}+$ concentration in substrate on $\mathrm{Na}^{+}(\mathrm{A})$ and $\mathrm{K}^{+}(\mathrm{B})$ concentration in different parts of of Tripleurospermum maritimum plants on dry mass basis. Data are means \pm SE from 5 individual plants. Asterisks indicate statistically significant differences $(p<0.05)$ from control.

respectively. $\mathrm{Na}^{+}$concentration in stem and flower tissues was significantly lower. There was a pronounced difference in $\mathrm{K}^{+}$concentration between plant parts, and it changed relatively little by salinity treatment, showing significant increase only in leaves at 2 and $5 \mathrm{~g} \mathrm{~L}^{-1} \mathrm{Na}$ (Fig. 4B).

Due to differences in water content between plant parts, $\mathrm{Na}+$ concentration on a tissue water basis was the highest in leaves, but it did not significantly increase in roots (Fig. $5 \mathrm{~A})$. Increase in $\mathrm{Na}^{+}$concentration in tissue water with rising substrate $\mathrm{Na}^{+}$concentration was near linear for stems, eventually reaching the same value as for leaves at 5 $\mathrm{g} \mathrm{L}^{-1} \mathrm{Na}^{+}$. Changes in summed tissue water concentration of $\mathrm{Na}^{+}+\mathrm{K}^{+}$were relatively minimally pronounced due to preferential accumulation of $\mathrm{K}^{+}$over $\mathrm{Na}^{+}$, with statistically significant increase at $5 \mathrm{~g} \mathrm{~L}^{-1}$ for flowers and stems, and 2 and $5 \mathrm{~g} \mathrm{~L}^{-1}$ for leaves (Fig. 5B).
Increase in electrolyte concentration in plant flowers, roots and leaves on a dry mass basis was relatively similar at low salinity, with significantly lower values in stems (Fig. $6 \mathrm{~A})$. Due to differences in tissue water content, increase of electrolyte concentration in roots was less pronounced than that in other plant parts (Fig. 6B).

\section{Effect of heavy metals on growth and metal accumulation} Shoot growth of T. maritimum was not significantly affected by substrate treatment with heavy metals up to $0.1 \mathrm{~g} \mathrm{~L}^{-1}$ $\mathrm{Cd}$ and $0.5 \mathrm{~g} \mathrm{~L}^{-1} \mathrm{~Pb}$ (Fig. 7A). However, root growth was significantly inhibited at $0.5 \mathrm{~g} \mathrm{~L}^{-1} \mathrm{~Pb}$, showing about $40 \%$ reduction of biomass (Fig. 7B). Water content in plant parts was relatively little affected by heavy metal treatment, with significant increase in flowers at 0.01 to $0.1 \mathrm{~g} \mathrm{~L}^{-1} \mathrm{Cd}$ (Fig. $8 \mathrm{~A}$ ) and 0.1 to $0.2 \mathrm{~g} \mathrm{~L}^{-1} \mathrm{~Pb}$ (Fig. $8 \mathrm{~B}$ ), and significant decrease
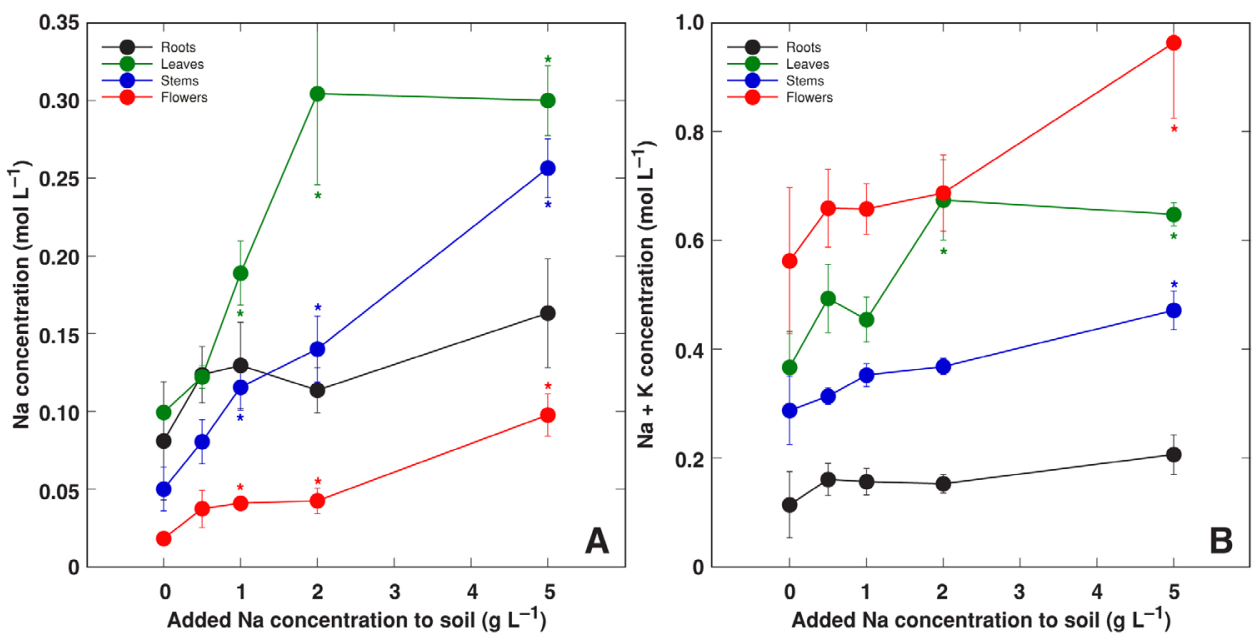

Fig. 5. Effect of increasing $\mathrm{Na}^{+}$concentration in substrate on $\mathrm{Na}^{+}(\mathrm{A})$ and $\mathrm{Na}^{+}+\mathrm{K}^{+}$(B) concentration in different parts of of Tripleurospermum maritimum plants on tissue water basis. Data are means \pm SE from 5 individual plants. Asterisks indicate statistically significant differences $(p<0.05)$ from control. 

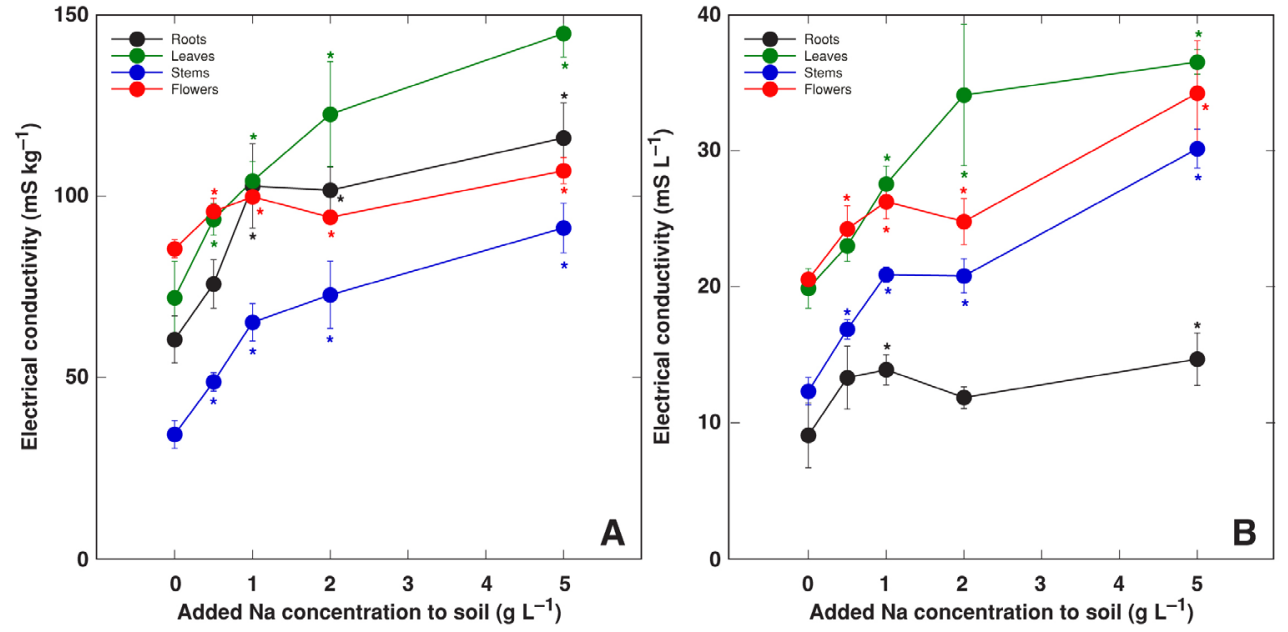

Fig. 6. Effect of increasing $\mathrm{Na}^{+}$concentration in substrate on electrolyte concentration on dry mass (A) and tissue water (B) basis in different parts of of Tripleurospermum maritimum plants on tissue water basis. Data are means \pm SE from 5 individual plants. Asterisks indicate statistically significant differences $(p<0.05)$ from control.
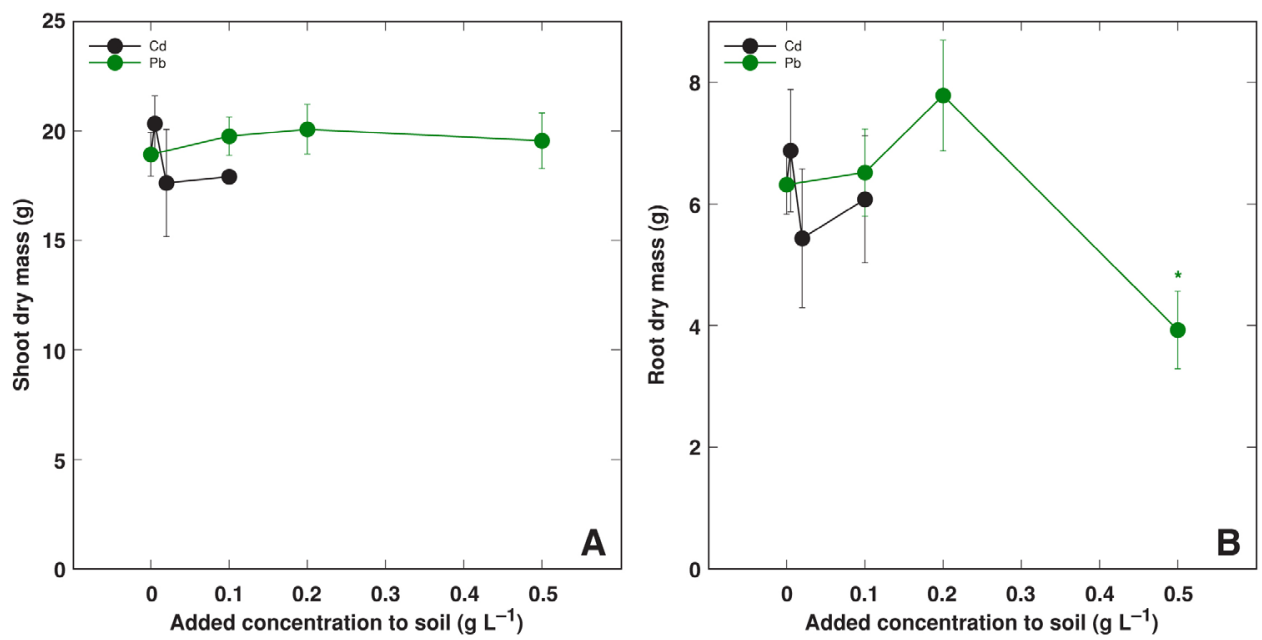

Fig. 7. Effect of increasing heavy metal concentration in substrate on dry mass of shoots (A) and roots (B) of Tripleurospermum maritimum plants after 7 weeks of cultivation. Data are means \pm SE from 5 individual plants. Asterisks indicate statistically significant differences $(p<0.05)$ from control.
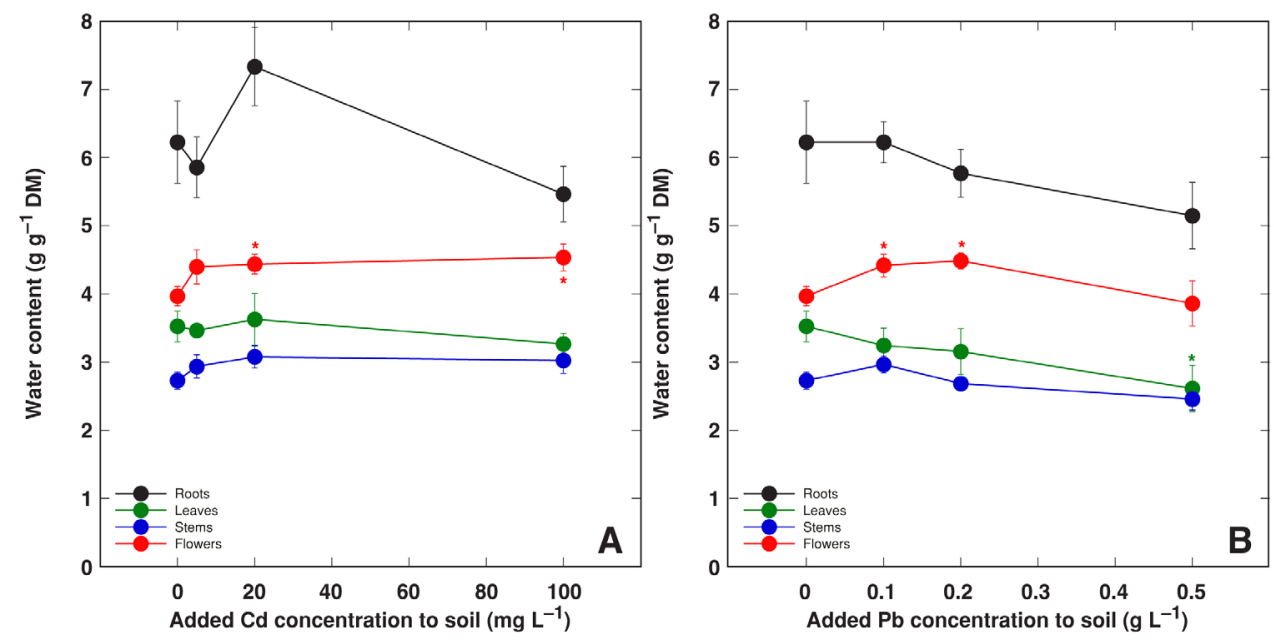

Fig. 8. Effect of increasing $\mathrm{Cd}(\mathrm{A})$ and $\mathrm{Pb}(\mathrm{B})$ concentration in substrate on water content in different parts of Tripleurospermum maritimum plants after 7 weeks of cultivation. Data are means \pm SE from 5 individual plants. Asterisks indicate statistically significant differences $(p<0.05)$ from control. 

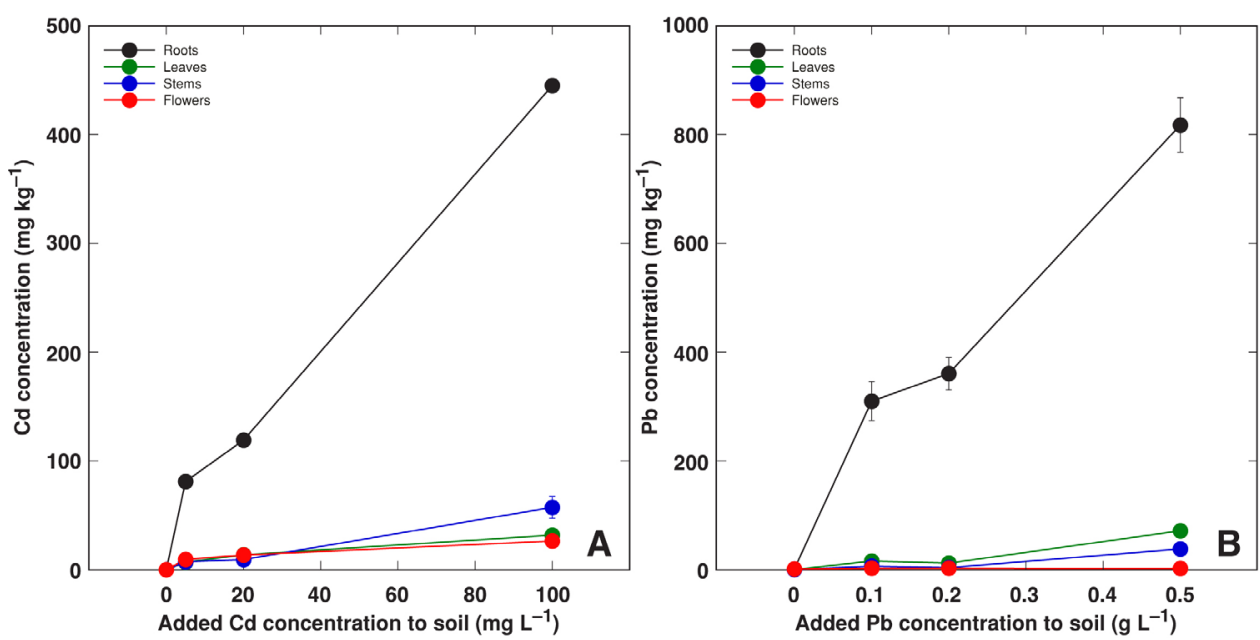

Fig. 9. Effect of increasing substrate $\mathrm{Cd}$ on accumulation of $\mathrm{Cd}(\mathrm{A})$ and increasing substrate $\mathrm{Pb}$ on accumulation of $\mathrm{Pb}(\mathrm{B})$ in different parts of Tripleurospermum maritimum plants after 7 weeks of cultivation. Data are means \pm SE from 3 individual plants.

in leaves at $0.5 \mathrm{~g} \mathrm{~L}^{-1} \mathrm{~Pb}$ (Fig. 8B). No visual symptoms of toxicity on plants were evident for either of the metals.

Both metals were preferentially accumulated in roots, with concentration in aboveground parts being only less than $10 \%$ from that in roots (Fig. 9). The highest level in root tissues was $445 \mathrm{mg} \mathrm{kg}^{-1}$ for Cd and $818 \mathrm{mg} \mathrm{kg}^{-1}$ for $\mathrm{Pb}$. At the maximum substrate concentration, stems $(57.5 \mathrm{mg}$ $\left.\mathrm{kg}^{-1}\right)$ accumulated more $\mathrm{Cd}$ than leaves $\left(32.0 \mathrm{mg} \mathrm{kg}^{-1}\right)$ and flowers $\left(26.8 \mathrm{mg} \mathrm{kg}^{-1}\right)$. However, greater $\mathrm{Pb}$ accumulation occurred in leaves $\left(71.8 \mathrm{mg} \mathrm{kg}^{-1}\right)$ than in stems $(38.5 \mathrm{mg}$ $\left.\mathrm{kg}^{-1}\right)$ and flowers $\left(3.0 \mathrm{mg} \mathrm{kg}{ }^{-1}\right)$. The relative accumulation potential for $\mathrm{Cd}$ was especially pronounced, with the bioconcentration factor reaching 15 at the lowest $\mathrm{Cd}$ dose.

\section{Discussion}

Predominant presence of T. maritimum plants in a seaaffected drift-line material-dependent shingle beach habitat indicates $s$ possible nitrophilic character and salinity tolerance of the species. In contrast to the M. maritima (T. maritimum) accession from sandy littoral dunes on the Atlantic coast of Brittany in France, being only occasionally affected by $\mathrm{NaCl}$ through salt sprays (Ben Hamed et al. 2014), plants from the accession of T. maritimum from a coastal shingle beach of the Baltic Sea used in the present study grew within $2 \mathrm{~m}$ from the waterline and were more or less continuously influenced by seawater.

High phenotypic plasticity of T. maritimum described previously (Kay 1994) was indeed supported by the results of the present study (Fig. 1). Both mineral nutrient availability and salinity significantly affected growth and morphology of the plants (Figs. 2 and 3). According to the results of the mineral nutrition experiment, T. maritimum plants were nitrophilous, as addition of surplus $\mathrm{N}$ fertilizer resulted in 20 to $30 \%$ increase in shoot biomass irrespective of fertilizer dose (Fig. 2). The species in Sweden has been characterized as having maximum possible nitrophily among vascular plants (Tyler et al. 2021). Indeed, plants growing on coastal drift-line material-affected habitats are usually considered nitrophilic (Jefferies 1977), as decomposition of wrack material consisting of vascular plant and macroalgal biomass leads to an extreme burst in local soil nitrogen concentration (Dugan et al. 2011; Rodil et al. 2019). However, no particular growth response values to added surplus nitrogen have been defined for putatively nitrophilic plant species in controlled conditions. Interestingly, another species from the same type of coastal habitat as T. maritimum, Rumex maritimus, showed a significantly more pronounced nitrophilic character, with more than four-fold leaf biomass increase by added nitrogen in controlled conditions (Ievinsh et al. 2020).

Salinity tolerance of T. maritimum plants in controlled conditions growing in soil can be characterized as moderate, as dry mass of shoots decreased by $38 \%$ and that of roots by $30 \%$ at $5 \mathrm{~g} \mathrm{~L}^{-1} \mathrm{Na}^{+}$(corresponding to 217 $\mathrm{mM})$. For comparison, in a study with an M. maritima (T. maritimum) accession from a sandy Atlantic coast in France, shoot dry biomass decreased by $20 \%$ and that of roots by $41 \%$ at $200 \mathrm{mM} \mathrm{NaCl}$ salinity (Ben Hamed et al. 2014). For a related species $M$. chamomilla, cultivated in hydroponics at $150 \mathrm{mM} \mathrm{NaCl}$, shoot growth was reduced by $76.3 \%$, but root growth even increased (Heidari, Sarani 2012).

It is important to note that ion accumulation characteristics of T. maritimum plants in conditions of controlled experiment were similar to those observed in natural conditions of saline coastal habitats of the Baltic Sea (Ievinsh et al. 2021). In the present study, leaves of $T$. maritimum accumulated up to $27 \mathrm{~g} \mathrm{~kg}^{-1} \mathrm{Na}^{+}$on a dry mass basis (in comparison, 7 to $23 \mathrm{~g} \mathrm{~kg}^{-1}$ in natural conditions), up to $0.30 \mathrm{~mol} \mathrm{~L}^{-1} \mathrm{Na}^{+}$in tissue water $\left(0.08\right.$ to $0.26 \mathrm{~mol} \mathrm{~L}^{-1}$ ), and electrical conductivity in tissue water reached $36 \mathrm{mS}$ $\mathrm{m}^{-1} \mathrm{~L}^{-1}$ ( 23 to $37 \mathrm{mS} \mathrm{m}^{-1} \mathrm{~L}^{-1}$ ). Consequently, the electrolyte concentration in leaves of T. maritimum plants grown in 
controlled conditions at relatively high substrate salinity was at the top electrolyte accumulation range of that found in natural conditions, with $\mathrm{Na}^{+}$and $\mathrm{K}^{+}$concentration even exceeding the respective ranges. M. maritima ( $T$. maritimum) plants from the Atlantic coast showed even more pronounced $\mathrm{Na}^{+}$accumulation potential, with shoot concentration for $\mathrm{Na}^{+}$reaching $4.5 \mathrm{mmol} \mathrm{g}$ (103.5 g $\mathrm{kg}^{-1}$; Ben Hamed et al. 2014). In contrast, hydroponicallycultivated M. chamomilla plants at $150 \mathrm{mM} \mathrm{NaCl}$ accumulated only 1.4 and $1.0 \mathrm{~g} \mathrm{~kg}^{-1}$ dry mass in shoots and roots, respectively (Heidari, Sarani 2012).

An important aspect of salinity tolerance was the fact that $\mathrm{K}^{+}$concentration in leaves of T. maritimum increased under salinity (Fig. 4B). In contrast, $\mathrm{K}^{+}$concentration in shoots and roots of $M$. chamomilla at $150 \mathrm{mM}$ salinity decreased by 37.6 and $46.1 \%$, respectively (Heidari, Sarani 2012). Increase in tissue $\mathrm{K}^{+}$concentration as a result of increasing substrate salinity is an important characteristic for defining salt-adapted facultatively-halophytic plant species (Munns, Tester 2008). However, obligate halophytic species are able to substitute $\mathrm{K}^{+}$for $\mathrm{Na}^{+}$as part of salinity tolerance mechanism (Belkheiri, Mulas 2013).

In the present study, root biomass of T. maritimum plants treated with $500 \mathrm{mg} \mathrm{L}^{-1} \mathrm{~Pb}$ was reduced only by $35 \%$ (Fig. 7B), while shoot growth was unaffected (Fig. 7A). Inhibition of root growth is a more sensitive indicator of $\mathrm{Pb}$ phytotoxicity in comparison to shoot growth, and even species hypertolerant to $\mathrm{Pb}$ show significant root growth reduction at relatively low $\mathrm{Pb}$ concentration in hydroponics (Mohtadi et al. 2012). Growth of T. maritimum plants was not affected even in $100 \mathrm{mg} \mathrm{L}^{-1} \mathrm{Cd}$ treatment (Fig 7), indicating especially high tolerance against this heavy metal. In conditions of hydroponics, unaltered growth of plants at $120 \mu \mathrm{M}\left(13 \mathrm{mg} \mathrm{L}^{-1}\right) \mathrm{Cd}$ concentration is considered as an indication of high Cd tolerance (Kováčik et al. 2006). For Cd-sensitive plants, several-fold decrease of plant biomass at $100 \mathrm{mg} \mathrm{kg}^{-1} \mathrm{Cd}$ in soil is a characteristic response (Anjum et al. 2014). In the case of $\mathrm{Pb}$ treatment in hydroponics, addition of $50 \mu \mathrm{M}\left(10 \mathrm{mg} \mathrm{L}^{-1}\right) \mathrm{Pb}$ usually results in significant decrease of shoot and root biomass for both non-metallophytes and facultative metallophytes (Fahr et al. 2015; Mohdavian et al. 2016). It is somehow more difficult to interpret response to increased $\mathrm{Pb}$ for soil-grown plants, due to chemical interaction of $\mathrm{Pb}$ in soil, considerably affecting its availability for plants (Shahid et al. 2012; Salazar et al. 2016). However, soil spiked with 400, 800 or $1200 \mathrm{mg} \mathrm{kg}^{-1} \mathrm{~Pb}$ has been frequently considered as representing low, medium, and high $\mathrm{Pb}$ levels, respectively (Ashraf, Tang 2017).

Preferential accumulation of $\mathrm{Pb}$ in roots in comparison to shoots represents a general pattern (Pourrut et al. 2011). Both $\mathrm{Cd}$ and $\mathrm{Pb}$ were preferentially accumulated in roots of T. maritimum, with concentration in aboveground parts being less than $10 \%$ from that in roots (Fig. 9). This feature allows the species to be considered as a typical heavy metal excluder. The taxonomically related species, $M$. chamomilla, in hydroponics also preferentially accumulated $\mathrm{Pb}$ in roots, with leaf $\mathrm{Pb}$ concentration being only $2.72 \mathrm{mg} \mathrm{kg}^{-1}$ (Grejtovský et al. 2008). A similar tendency was noted for $\mathrm{Cd}$ accumulation in $M$. chamomilla, but the potential for metal accumulation in leaves was higher, reaching $300 \mathrm{mg}$ $\mathrm{kg}^{-1} \mathrm{Cd}$ (Kovačik et al. 2009).

When characterizing plant tolerance to heavy metals, concentration of a particular metal in leaf tissues of plants is more important indicator that that in soil. The majority of plants have threshold sensitivity to tissue $\mathrm{Cd}$ concentration range at 5 to $10 \mathrm{mg} \mathrm{kg}^{-1}$, and that for $\mathrm{Pb}$ in a range 10 to $20 \mathrm{mg} \mathrm{kg}^{-1}$ (White, Brown 2010). Consequently, given the fact that growth of T. maritimum plants was unaffected at $32 \mathrm{mg} \mathrm{kg}^{-1}$ leaf $\mathrm{Cd}$ concentration and at $12.8 \mathrm{mg} \mathrm{kg}^{-1}$ leaf $\mathrm{Pb}$ concentration, the species can be characterized as hypertolerant to $\mathrm{Cd}$ and tolerant to $\mathrm{Pb}$.

In conclusion, the coastal accession of T. maritimum from a shingle beach is moderately nitrophylic with high salinity tolerance and high electrolyte accumulation potential in shoots, with preferred accumulation of $\mathrm{K}^{+}$over $\mathrm{Na}^{+}$. The species show very high tolerance to heavy metals $\mathrm{Cd}$ and $\mathrm{Pb}$, with characteristic exclusion of the metals from aboveground parts.

\section{References}

Andersone-Ozola U., Jēkabsone A., Purmale L., Romanovs M., Ievinsh G. 2021. Abiotic stress tolerance of coastal accessions of a promising forage legume species, Trifolium fragiferum. Plants 10: 1552.

Anjum N.A., Umar S., Iqbal M. 2014. Assessment of cadmium accumulation, toxicity, and tolerance in Brassicaceae and Fabaceae plants - implications for phytoremediation. Environ. Sci. Pollut. Res. 21: 10286-10293.

Ashraf U., Tang X. 2017. Yield and quality responses, plant metabolism and metal distribution pattern in aromatic rice under lead $(\mathrm{Pb})$ toxicity. Chemosphere 176: 141-155.

Baghalian K., Haghiry A., Naghavi M.R., Mohammadi A. 2008. Effect of saline irrigation water on agronomical and phytochemical characters of chamomile (Matricaria recutita L.). Sci. Hortic. 116: 437-441.

Belkheiri O., Mulas M. 2013. The effects of salt stress on growth, water relations and ion accumulation in two halophyte Atriplex species. Environ. Exp. Bot. 86: 17-28.

Ben Hamed K., Chibani F., Abdelly C., Magne C. 2014. Growth, sodium uptake and antioxidant responses of coastal plants differing in their ecological status under increasing salinity. Biologia 69: 193-201.

Corner R. 2012. A flourishing population of sea mayweed (Tripleurospermum maritimum ssp. phaeocephalum) close to its northern limit in north-east Greenland. Polar Res. 31: 18691.

Dugan J.E., Hubbard D.M., Page H.M., Schimel J.P. 2011. Marine macrophyte wrack inputs and dissolved nutrients in beach sands. Estuaries Coasts 34:839-850.

EC. 2013. Interpretation Manual of European Union Habitats EUR28. European Comission DG Environment, 144 p.

Fahr M., Laplaze L., El Mzibri M., Doumas P., Bendaou N., Hocher 
V., Bogusz D., Smouni A. 2015. Assessment of lead tolerance and accumulation in metallicolous and non-metallicolous populations of Hirschfeldia incana. Environ. Exp. Bot. 109: 186-192.

Farzadfar S., Zarinkamar F., Modarres-Sanavy S.A.M., Hojati M. 2013. Exogenously applied calcium alleviates cadmium toxicity in Matricaria chamomilla L. plants. Envrion. Sci. Pollut. Res. 20: 1413-1422.

Grejtovský A., Markušová K., L. Nováková L. 2008. Lead uptake by Matricaria chamomilla L. Plant Soil Environ. 54: 47-54.

Heidari M., Sarani S. 2012. Growth, biochemical components and ion content of Chamomile (Matricaria chamomilla L.) under salinity stress and iron deficiency. J. Saudi Soc. Agric. Sci. 11: 37-42.

Ievinsh G. 2006. Biological basis of biological variability: physiological adaptations of plants to heterogeneous habitats along a sea coast. Acta Univ. Latv. 710: 53-79.

Ievinsh G., Ievina S., Andersone-Ozola U., Samsone I. 2021. Leaf sodium, potassium and electrolyte accumulation capacity of plant species from salt-affected coastal habitats of the Baltic Sea: Towards a definition of $\mathrm{Na}$ hyperaccumulation. Flora 274: 151748.

Ievinsh G., Landorfa-Svalbe Z., Andersone-Ozola U., Bule A. 2020. Wild Rumex species as models in ecophysiological studies: effect of $\mathrm{Na} / \mathrm{K}$ salts and nitrogen compounds on growth and electrolyte accumulation. Environ. Exp. Biol. 18: 43-44.

Jefferies R.L. 1977. Growth responses of coastal halophytes to inorganic nitrogen. J. Ecol. 65: 847-865.

Kay Q.O.N. 1972. Variation in sea mayweed (Tripleurospermum maritimum (L.) Koch) in the British isles. Watsonia 9: 81-107.

Kay Q.O.N. 1994. Tripleurospermum inodorum (L.) Schultz Bip. J. Ecol. 82: 681-697.

Kováčik J., Grúz J., Bačkor M., Tomko J., Strnad M., Repčák M. 2008. Phenolic compounds composition and physiological attributes of Matricaria chamomilla grown in copper excess. Envrion. Exp. Bot. 62: 145-152.

Kováčik J., Klejdus B., Hedbavny J., Štork F., Bačkor M. 2009. Comparison of cadmium and copper effect on phenolic metabolism, mineral nutrients and stress-related parameters in Matricaria chamomilla plants. Plant Soil 320: 231-242.

Kováčik J., Klejdus B., Kaduková J., Bačkor M. 2009. Physiology of Matricaria chamomilla exposed to nickel excess. Ecotoxicol. Environ. Safety 72: 603-609.

Kováčik J., Tomko J., Bačkor M., Repčák M. 2006. Matricaria chamomilla is not a hyperaccumulator, but tolerant to cadmium stress. Plant Growth Regul. 50: 239-247.

Mohdavian K., Ghaderian S.M., Schat H 2016. Pb accumulation, $\mathrm{Pb}$ tolerance, antioxidants, thiols, and organic acids in metallicolous and non-metallicolous Peganum harmala L. under $\mathrm{Pb}$ exposure. Environ. Exp. Bot. 126: 21-31.

Mohtadi A., Ghaderian S.M., Schat H. 2012. A comparison of lead accumulation and tolerance among heavy metal hyperaccumulating and non-hyperaccumulating metallophytes. Plant Soil 352: 267-276.

Munns R., Tester M. 2008. Mechanisms of salinity tolerance. Annu. Rev. Plant Biol. 59: 651-681.

Pavlovič A., Masarovičová E., Králová K., Kubová J. 2006. Response of chamomile plants (Matricaria recutita L.) to cadmium treatment. Bull. Environ. Contam. Toxicol. 77: 763771.

Pourrut B., Shahid M., Dumat C., Winterton P., Pinelli E. 2011. Lead uptake, toxicity, and detoxification in plants. In: Whitacre D.M. (Ed) Reviews of Environmental Contamination and Toxicology. Springer, New York, pp. 113-136.

Razmjoo K., Heydarizadeh P., Sabzalian M.R. 2008. Effect of salinity and drought stress on growth parameters and essential oil content of Matricaria chamomila. Int. J. Agric. Biol. 10: 451-454.

Rinkis G.J., Ramane H.K., Kunickaya T.A. 1987. Methods of Soil and Plant Analysis. Zinatne, Riga, 174 p. /in Russian/

Rodil I.F., Lastra M., López J., Mucha A.P., Fernandes J.P., Fernandes S.V., Olabarria C. 2019. Sandy beaches as biogeochemical hotspots: the metabolic role of macroalgal wrack on low-productive shores. Ecosystems 22: 49-63.

Salazar M.J., Rodriguez J.H., Cid C.V., Bernardelli C.E., Domati E.R., Pignata M.L. Soil variables that determine lead accumulation in Bidens pilosa L. and Tagetes minuta L. growing in polluted soils. Geoderma 279: 97-108.

Shahid M., Pinelli E., Dumat C. 2012. Review of Pb availability and toxicity to plants in relation with metal speciation; role of synthetic and natural organic ligands. J. Hazard. Mater. 219220: $1-12$.

Tyler T., Herbertsson L., Olofsson J., Olsson P.A. 2021. Ecological indicator and traits values for Swedish vascular plants. Ecol. Indic. 120: 106923.

Voyslavov T., Georgieva S., Arpadjan S., Tsekova K. 2013. Phytoavailability assessment of cadmium and lead in polluted soils and accumulation by Matricaria chamomilla (chamomile). Biotechnol. Biotechnol. Equipm. 27: 3939-3943.

White P.J., Brown P.H. 2010. Plant nutrition for sustainable development and global health. Ann. Bot. 105: 1073-1080. 